Article

\title{
High Academic Self-Efficacy and Dispositional Empathy in Future Teachers
}

\author{
María Pilar Aparicio-Flores ${ }^{1, *}{ }^{\mathbb{C}}$, José María Esteve-Faubel ${ }^{2} \mathbb{D}$, Rosa Pilar Esteve-Faubel ${ }^{2} \mathbb{D}$ and \\ José Daniel Álvarez-Teruel ${ }^{1}$ \\ 1 Department of Developmental Psychology and Teaching, Faculty of Education, University of Alicante, \\ 03690 Alicante, Spain; josedaniel.alvarez@ua.es \\ 2 Department of General Didactic and Specific Didactics, Faculty of Education, University of Alicante, \\ 03690 Alicante, Spain; jm.esteve@ua.es (J.M.E.-F.); rosapilar.esteve@ua.es (R.P.E.-F.) \\ * Correspondence: pilar.aparicio@ua.es; Tel.: +34-965903400 (ext. 1210)
}

Received: 19 July 2020; Accepted: 18 August 2020; Published: 19 August 2020

\begin{abstract}
High perceived academic self-efficacy influences both subject performance and emotions of the subject. In turn, dispositional empathy implies a social and emotional adaptability towards the subject itself and those around them. This study aimed to analyze the differences in the mean dispositional empathy factors (i.e., perspective taking, fantasy, empathic concern and personal distress) between future teachers with high and low perceived academic self-efficacy, as well as the predictive capacity of dispositional empathy on high perceived academic self-efficacy, and the correlations between both dimensions. For this, a sample of 805 Spanish students of the Faculties of Education of the Universities of Alicante and Murcia was recruited. The Escala de Autoeficacia Percibida Específica de Situaciones Académicas was used to assess perceived academic self-efficacy and the Interpersonal Reactivity Index was used to analyze the dimensions of dispositional empathy. It was observed that high academic self-efficacy is more likely to present in people with a high level of perspective taking and fantasy $(O R=1.06$ and 1.09, respectively) and less for those with personal discomfort $(O R=0.86)$. The other analyzes provided the same conclusions. In conclusion, it is important to develop perceived academic self-efficacy in undergraduates and future teachers due to the consequences that can lead to their classrooms.
\end{abstract}

Keywords: perceived academic self-efficacy; dispositional empathy; undergraduates; future teachers

\section{Introduction}

There is a lack of studies analyzing the link between levels of dispositional empathy and all its factors (i.e., perspective taking, fantasy, empathic concern, and personal discomfort) with perceived academic self-efficacy.

It is important to know the level of dispositional empathy that university students have based on perceived academic self-efficacy. Specifically, it is important to measure this link in future teachers, since previous studies show that higher levels of work stress are experienced with a lower degree of self-efficacy, which leads to a lack of confidence to manage, design activities and strategies to instruct in the classroom [1]. Other studies show that teachers with a high degree of self-efficacy tend to manifest a decrease in stress [2], and that a high level of self-efficacy is linked to greater job satisfaction, which is related to positive attitudes, enjoyment at work, happiness and higher performance [3].

\subsection{Perceived Academic Self-Efficacy}

Self-efficacy and empathy are two constructs that directly influence academic performance and social interaction [4-7]. Self-efficacy, in the academic field, is understood as the student's belief in 
their abilities to undertake those activities that are required of them in the educational context $[8,9]$. Research in this area has shown that the high-performance levels of adolescents with high perceived academic self-efficacy are often accompanied by high grades and academic success attributable to causes such as ability or effort [9-11].

Research conducted with adolescents and university students has analyzed the link between perceived academic self-efficacy and the development of the academic self-concept [10,12], feelings of control and confidence [13], motivation [14] and cognitive-emotional variables such as self-regulation of learning [15]. Self-regulation of learning is understood as an important motivational process that increases expectations for success and learning goals by contributing to greater initiative and perseverance in tasks [16]. Task motivation triggers greater efforts toward learning [17]. In fact, expectations for success greatly influence professional choices for students due to increased task motivation [17].

On the other hand, studies that examine psycho-emotional variables show that self-efficacy determines an adequate regulation of stress, which is considered positive when it is estimated that the learning goal is achieved with effort [15], and even with positive feelings before the development of the activity when it is supported by mastery and performance objectives [18] and the probability of success is considered [19]. It has been observed that academic self-efficacy is a predictor of academic resilience [20], which is the capacity of students to maintain high motivation and academic performance, even when they are faced with situations of adversity and stress [6].

Gender and age also influence the degree of self-efficacy, since studies have demonstrated that there are differences in this at the academic, social, and sports levels [21]. In adolescents, self-efficacy and performance expectations are linked to greater use of technology and social networks [22]. In university students, self-efficacy is linked to all dimensions of psychological well-being such as self-acceptance, environment domain, purpose in life, personal growth, autonomy, and positive relationships [23], as well as a higher degree of employment [24] and to future job prospects [25]. Some studies indicate an increase in academic self-efficacy as a result of teamwork [26], which includes the management of empathy as an innate competence [27]. For this reason, a lower level of academic self-efficacy can report negative consequences, both in academic performance and in the personal sphere, causing effects both at the individual and collective level, regarding the student's work group [4].

\subsection{Dispositional Empathy}

Empathy is understood as the ability to experience another person's state of mind, which implies an interpersonal adaptative interaction [28,29]. In the literature, two types of empathy are differentiated: dispositional and situational. In dispositional empathy, the level of empathy is outside of a particular situation, which is why it is considered stable in the person [30]. In other words, dispositional empathy is understood as the tendency to imagine the situations or perspectives of other people in different contexts, which some studies describe as the cognitive dimension of empathy [31].

Dispositional empathy is made up of factors such as perspective taking (it is known as the tendency to accept the point of view that someone else can provide), fantasy (which marks the person's inclination to identify with unreal characters that appear in movies or books), empathic concern (known as the person's propensity to feel compassion and concern for others) and personal discomfort (which is known as the tendency to experience an uncomfortable and anxious feeling when witnessing a negative situation) [32].

Rameson, Morelli and Lieberman [33] indicate that dispositional empathy generates empathetic reactions automatically. However, situational empathy is influenced by social capacity towards a specific situation [7], which is generated in more specific contexts [30]. In this regard, it should be noted that dispositional empathy generates positive mental states in the person with whom one interacts, unlike empathy generated with a target [34]. In other words, dispositional empathy is linked to a positive emotional state that generates feelings of happiness [34]. In fact, dispositional empathy towards the other person implies an improvement in social interaction because the understanding and 
appreciation of the other is more complete [34]. It seems that a subject with dispositional empathy tends to manifest a high spirit of objectives, even when distressed at the beginning of the task. However, it is not entirely so if the person have is an empathetic mentality or motivation to be empathetic, but not dispositional empathy specifically. As a matter of fact, at the same time, a person interacting with another person with high dispositional empathy gains a positive state of mind compared to someone who has simply been asked to be empathetic [34].

\subsection{Perceived Academic Self-Efficacy and Dispositional Empathy}

While it is true that empathy-based strategies are the focus of many educational interventions [34], there are few studies that assess the link between perceived academic self-efficacy and dispositional empathy in a specific way.

Dionigi, Casu and Gremigni [35] analyzed whether dispositional empathy was associated with self-efficacy, optimism, mental health and subjective well-being in volunteer hospital clowns. The authors found only positive and significant correlations in the dimensions of perspective taking and empathic concern with self-efficacy, optimism, mental health, and subjective well-being. Personal discomfort negatively correlated with self-efficacy and optimism; however, fantasy did not obtain significance. Likewise, under regression analysis, the authors observed that, although perspective taking had beneficial effects, observing how other people suffer could negatively affect the psychological well-being of the volunteers. Similarly, it was observed that personal discomfort was related to a worse subjective and psychological well-being when empathizing the feelings of the other under a negative affectivity [35].

It should be noted, from the items of the Interpersonal Reactivity Index (IRI) [32], that perspective taking empathy tries to understand others, and fantasy empathy fantasizes about how they feel about fictional characters that appear in a novel or in a movie that they are reading or watching. However, empathic concern compassionately empathizes with others, and personal discomfort empathizes with people activating a feeling of fear, anxiety and loss of control. In this sense, it should be considered that fear activates the negative consequences of failure [36], anxiety negatively influences self-efficacy [37] and control beliefs in students contribute to higher performance goals [38]. In fact, authors such as Dionigi et al. [35] affirm that personal discomfort can generate a negative affect when putting oneself in the situation that another person is experiencing, and that a low academic self-efficacy predicts emotional exhaustion [4].

Perceived Academic Self-Efficacy and Dispositional Empathy in Teachers

Regarding teachers, a negative belief of self-efficacy can trigger burnout syndrome, with negative social consequences and distant behavior $[39,40]$. Similarly, it has been observed that a lower degree of self-efficacy implies higher levels of work stress [1] and vice versa [2].

It is very important that teachers have high self-efficacy not only for their ability to organize and to set goals, but also to feed their behavior and motivation, as well as their commitment and enthusiasm [41]. According to Goroshit and Hen [41], self-efficacy in teachers predicts empathy.

Teachers with low self-efficacy appear to have fewer strategies for managing student behavior, leading to higher levels of stress, and use disciplinary strategies based on punishment. Instead, teachers with high self-efficacy use more open and organized strategies and work from a more humanistic and integrative approach [41]. If a teacher has greater abilities to recognize the emotions of the students, they will be better able to motivate their learning, at the same time that they generate their own emotional regulation, which will also influence the relationship with others [42].

All these findings make us reflect on how the emotional and organizational stability of a teacher can affect students. This situation could be prejudiced by the students, and the school is one of the main focus of socialization involving the entire educational community.

Teachers who perceive and understand the students' point of view play a fundamental role in their learning [7]. Therefore, given the importance of the teacher's role in the classroom [1] and that 
this is conditioned by the interpersonal ability that university students must have in their future job, it is necessary to assess the degree of dispositional empathy as a function of perceived academic self-efficacy that, in this case, the future teachers of Early Childhood and Primary Education possess, while they are students of the Faculties of Education.

\subsection{The Present Study}

\subsubsection{Objectives}

After examining the previous literature regarding the link between perceived academic self-efficacy and dispositional empathy, as well as all its factors, several limitations are found. In the first place, no studies have been found that accurately examine the variables shown in this work. Secondly, previous studies lack the magnitude of the differences on the analysis of logistic models, which hinders the theoretical and practical interpretation of the results.

Likewise, most studies show the importance of maintaining high academic self-efficacy and dispositional empathy, as well as a link between both. However, in the study by Dionigi et al. [35], it was observed that not all the factors of dispositional empathy obtained a link with self-efficacy.

Considering previous limitations, the present study aims to (a) establish the correlations between perceived academic self-efficacy and dispositional empathy factors, (b) analyze the differences between perceived academic self-efficacy and dispositional empathy factors, and (c) analyze the predictive capacity of dispositional empathy factors on high perceived academic self-efficacy.

\subsubsection{Hypothesis}

Considering the previous literature that warns that high self-efficacy is linked to greater job satisfaction, which in turn triggers a positive attitude [3] and, conversely, that a low self-efficacy or negative belief of self-efficacy conditions the person's behavior and socialization $[39,40]$ and increases work stress [1], it could be considered that dispositional empathy will have a positive link with high academic self-efficacy. However, as noted from the study by Dionigi et al. [35], not all dimensions could have a positive and significant link.

For this reason, from the reviewed literature, it is expected that:

Hypothesis 1. Positive correlations are obtained with perspective taking and empathic concern.

Hypothesis 2. Negative and significant correlations are obtained with personal discomfort.

Hypothesis 3. Significant differences are obtained in the mean scores of the dispositional empathy factors based on the perceived high or low academic self-efficacy, except for fantasy.

Hypothesis 4. High perceived academic self-efficacy presents significantly higher means in the dimensions of perspective taking and empathic concern, than students with low perceived academic self-efficacy.

Hypothesis 5. The low perceived academic self-efficacy presents higher significant means in the dimension of personal discomfort than the high perceived academic self-efficacy.

Hypothesis 6. The probability of presenting a high perceived academic self-efficacy is greater as the dimensions of perspective taking and empathic concern increase.

Hypothesis 7. The probability of presenting a high perceived academic self-efficacy is less as personal discomfort increases. 


\section{Materials and Methods}

\subsection{Participants}

The sample of participants was recruited by means of a non-probabilistic sampling, taking the degree as the primary unit, the course as the secondary unit, and the group as tertiary unit, and was made up of 834 students in the Degree of Early Childhood Education and Primary Education teacher enrolled in the Faculties of Education of the universities of Alicante and Murcia. Of these, 29 (3.48\%) participants were excluded for not completing the questionnaire correctly, so the total sample consisted of 805 students.

As shown in Table 1, there was greater participation of women (63.60\%). Regarding age, the participants were mainly in the range of 18 to 25 years $(86.34 \%)$. Likewise, it was observed that $77.64 \%$ studied, while $22.3 \%$ studied and worked.

Table 1. Description of the participants.

\begin{tabular}{|c|c|c|}
\hline Variables & & $N(\%)$ \\
\hline \multirow{2}{*}{ Gender } & Women & $512(63.60 \%)$ \\
\hline & Men & $293(36.40 \%)$ \\
\hline \multirow{3}{*}{ Age } & R1(aged between 18 and 25 years) & $695(86.34 \%)$ \\
\hline & R2 (aged between 26 and 36 years) & $83(10.31 \%)$ \\
\hline & R3 (aged between 36 and 37 years) & $27(3.35 \%)$ \\
\hline \multirow{2}{*}{ Socio-economic level } & Study & $625(77.64 \%)$ \\
\hline & Study and work & $180(22.36 \%)$ \\
\hline
\end{tabular}

\subsection{Measures}

Escala de Autoeficacia Percibida Específica de Situaciones Académicas (EAPESA) [10]. The Spanish version of the Specific Perceived Self-Efficacy Scale of Academic Situations [10] was adapted from Palenzuela [43]. It is composed of 10 items that constitute a one-dimensional scale. It assesses self-efficacy expectations in specific contexts of the educational environment, for both high school and university students (e.g., 'I consider myself qualified enough to successfully complete any academic task'). EAPESA is a scale with Likert-type responses $(1=$ Never; $4=$ Always $)$, in which a higher score indicates a higher level of self-efficacy.

The validation of the EAPESA in Peru, with a sample of university students [44], and in Spain, with students from Compulsory Secondary Education [10], provide adequate psychometric properties and also support the unidimensional nature of this scale. For the present study, Cronbach's alpha coefficient was 0.88 .

Interpersonal Reactivity Index (IRI) [32]. The IRI is a scale made up of 28 items with Likert-type responses ( 0 = Does not describe me well; $4=$ Describes me very well), measuring dispositional empathy. The scale is composed of 4 factors: I. perspective taking (i.e., Before criticizing someone, I try to imagine how I would feel if I were in their position), with 7 items referring to the ability to put oneself in the others' position; II. fantasy (i.e., When I am reading an interesting novel or story, I imagine how I would feel if what happened in the story was happening to me), composed of 7 items, which assess the tendency to identify with imaginary people or situations; III. empathic concern (i.e., I am often moved by the things I see happening), with 8 items referring to compassion and concern for others; and IV. personal discomfort (i.e., It scares me to be in a tense emotional situation), with 6 items that assess that discomfort and anxiety in the face of negative experiences. The psychometric properties of the Spanish version of the scale were appropriate [32], as well as for the present study $(\alpha=0.70,0.78,0.69$, and 0.72 , respectively). 


\subsection{Procedure}

In the first place, an interview was conducted with the teachers of participating students to present the objectives of the study, describe the questionnaires, and request their collaboration. Subsequently, the study was explained to participants and participation consent was requested; tests were collectively administered in the classroom for approximately $20 \mathrm{~min}$. Demographic data were collected according to age, gender, and socio-economic level. The questionnaires were completed anonymously and voluntarily and the written informed consent of the participants was requested. This research was carried out following the rules of the Declaration of Helsinki of 1975.

\subsection{Data Analysis}

Firstly, the distribution of scores was analyzed and correlations between variables were examined. Likewise, to identify future teachers with more or less perceived academic self-efficacy, participants were divided into two groups: (a) students with high self-efficacy: scores equal to or greater than the 75th percentile $(n=266)$; and (b) students with low self-efficacy: scores equal to or below the 25th percentile $(n=198)$. The Student's t-test was used for comparing the differences between the means for independent measures in the mean scores obtained in perspective taking, fantasy, empathic concern, and personal discomfort. The standardized mean difference (index $d$ ) proposed by Cohen [45] was included to assess the magnitude of the differences found with the following interpretations: values between 0.20 and 0.50 for a small effect size, values between 0.51 and 0.79 for a moderate effect size, and equal of greater than 0.80 for a large effect size.

To identify high perceived academic self-efficacy as function of the dispositional empathy variables, the statistical technique of logistic regression was used, by means of the Wald step forward statistics, to check the goodness of fit of the model, the Hosmer and Lemeshow test was used. The purpose of this technique is to quantify the influence of probability in which a variable or event appears or is absent, as well as their values. In this manner, the logistic model used estimates the probability in which an event occurs or not, in the presence of one or more predictors (i.e., high or low self-efficacy; in the presence of dispositional empathy). Its probability is estimated through the mean odds ratio $(O R)$, interpreting it according to the following results: values below 1 indicate negative predictions, value 1 indicates that there is no prediction, and values above 1 indicate positive predictions [46].

\section{Results}

\subsection{Distribution of Items}

The items were distributed within the range [0-1.96], the asymmetry oscillating between -0.24 (item 7) and 0.49 (item 9) for perceived academic self-efficacy, and between -1.46 (item 4 of factor Empathic concern) and 1.36 (item 27 of factor Personal discomfort) for dispositional empathy. Likewise, the kurtosis values for perceived academic self-efficacy ranged between -0.63 (item 9) and -0.08 (item 7), and for dispositional empathy the values ranged between -0.82 (item 16 of factor Fantasy) and 1.51 (item 18 of factor Empathic concern) (see Table 2). 
Table 2. Kurtosis and asymmetry of the EAPESA and IRI items.

\begin{tabular}{|c|c|c|c|c|c|c|c|c|c|c|c|c|c|c|}
\hline \multicolumn{3}{|c|}{ Self-Efficacy } & \multicolumn{3}{|c|}{$\begin{array}{l}\text { Perspective } \\
\text { Taking }\end{array}$} & \multicolumn{3}{|c|}{ Fantasy } & \multicolumn{3}{|c|}{$\begin{array}{l}\text { Empathic } \\
\text { Concern }\end{array}$} & \multicolumn{3}{|c|}{$\begin{array}{c}\text { Personal } \\
\text { Discomfort }\end{array}$} \\
\hline I & $\mathbf{A}$ & $\mathbf{K}$ & I & $\mathbf{A}$ & $\mathbf{K}$ & I & A & $\mathbf{K}$ & I & A & $\mathbf{K}$ & I & $\mathbf{A}$ & $\mathbf{K}$ \\
\hline 1 & -0.16 & -0.14 & 3 & -0.85 & 0.04 & 1 & -0.53 & -0.26 & 2 & -0.46 & 0.03 & 6 & 0.13 & -0.54 \\
\hline 2 & -0.10 & -0.37 & 8 & -0.27 & -0.14 & 5 & -0.10 & -0.75 & 4 & -1.46 & 1.02 & 10 & 0.01 & -0.65 \\
\hline 3 & -0.17 & -0.15 & 11 & -0.48 & 0.27 & 7 & -0.62 & -0.06 & 9 & -0.65 & 0.39 & 17 & 0.09 & -0.65 \\
\hline 4 & 0.20 & -0.32 & 12 & 1.05 & 0.39 & 12 & -1.05 & 0.39 & 13 & -0.52 & -0.78 & 19 & -0.15 & -0.20 \\
\hline 5 & 0.26 & -0.33 & 15 & -0.56 & -0.37 & 16 & 0.18 & -0.82 & 14 & -1.30 & 0.97 & 24 & 0.62 & -0.12 \\
\hline 6 & -0.23 & -0.12 & 21 & -0.29 & 0.09 & 23 & -0.25 & -0.62 & 18 & -1.43 & 1.51 & 27 & 1.36 & 1.43 \\
\hline 7 & -0.24 & -0.08 & 25 & 0.16 & -0.28 & 26 & -0.17 & -0.53 & 20 & -0.41 & 0.28 & & & \\
\hline 8 & -0.12 & -0.50 & 28 & -0.03 & -0.48 & & & & & & & & & \\
\hline 9 & 0.49 & -0.63 & & & & & & & & & & & & \\
\hline 10 & -0.16 & -0.44 & & & & & & & & & & & & \\
\hline
\end{tabular}

Note: I = Item; A = Asymmetry; $\mathrm{K}=$ Kurtosis.

\subsection{Correlations between Perceived Academic Self-Efficacy and Dispositional Empathy}

The correlations were statistically significant and with a positive sign between perceived academic self-efficacy and perspective taking and fantasy, and with a negative sign with personal discomfort. Among the IRI factors, the positive and statistically correlations were identified among all the factors except for the associations between Personal discomfort and Empathic Concern (see Table 3).

Table 3. Correlations between perceived academic self-efficacy and dispositional empathy factors.

\begin{tabular}{ccccc}
\hline & Self-Efficacy & Perspective Taking & Fantasy & Empathic Concern \\
\hline Perspective taking & $0.11^{*}$ & & & \\
Fantasy & $0.13^{* *}$ & $0.20^{* *}$ & $0.38^{* *}$ & \\
Empathic Concern & 0.03 & $0.35^{* *}$ & $0.10^{*}$ & 0.05 \\
Personal discomfort & $-0.18^{* *}$ & -0.04 & \\
\hline
\end{tabular}

Note: ${ }^{*} p<0.05,{ }^{* *} p<0.001$.

\subsection{Mean Difference}

Table 4 shows the differences observed between the participants with high and low perceived academic self-efficacy in the mean scores of the dispositional empathy dimensions (perspective taking, fantasy, empathic concern, and personal discomfort), as well as the effect size of both variables.

Table 4. Means and standard deviation of perceived academic self-efficacy in function of the dispositional empathy.

\begin{tabular}{|c|c|c|c|c|c|c|c|c|}
\hline \multirow[b]{2}{*}{$\begin{array}{l}\text { Dimensions of } \\
\text { the IRI }\end{array}$} & \multicolumn{2}{|c|}{$\begin{array}{l}\text { Levene } \\
\text { Test }\end{array}$} & \multicolumn{2}{|c|}{$\begin{array}{c}\text { High } \\
\text { Self-Efficacy } \\
\text { Group }\end{array}$} & \multicolumn{2}{|c|}{$\begin{array}{c}\text { Low Self-Efficacy } \\
\text { Group }\end{array}$} & \multicolumn{2}{|c|}{$\begin{array}{c}\text { Statistical } \\
\text { Significance }\end{array}$} \\
\hline & $F$ & $p$ & $M$ & $S D$ & $M$ & $S D$ & $t$ & $p$ \\
\hline Perspective taking & 2.45 & 0.118 & 24.63 & 3.81 & 23.78 & 3.29 & 2.51 & 0.012 \\
\hline Fantasy & 4.45 & 0.035 & 23.71 & 3.55 & 22.44 & 4.07 & 3.50 & 0.001 \\
\hline Empathic concern & 0.01 & 0.925 & 30.64 & 3.48 & 30.47 & 3.45 & 0.52 & 0.598 \\
\hline Personal discomfort & 9.93 & 0.002 & 13.96 & 3.29 & 15.36 & 2.63 & -5.09 & $<0.001$ \\
\hline
\end{tabular}

Participants with high perceived academic self-efficacy show significantly higher mean in perspective taking and fantasy than those with low self-efficacy, with the magnitude of these differences being low in both cases $(d=0.24, d . f .=462$; and $d=0.34, d . f$. $=390.29$, respectively). Likewise, 
the personal discomfort score is significantly higher in the group with low perceived self-efficacy $(d=0.46, d . f .=459.61)$.

\subsection{Predictive Capacity of Dispositional Empathy on High Perceived Academic Self-Efficiency}

The results of presenting high perceived academic self-efficacy as a function of dispositional empathy, or more specifically, as a function of the variables of perspective taking, fantasy, and personal discomfort are presented in Table 5.

Table 5. Binary logistic regression for the probability of high self-efficacy in function of the perspective taking, fantasy, and personal discomfort variables.

\begin{tabular}{|c|c|c|c|c|c|c|c|c|}
\hline Variable & & & B & E.T. & Wald & $p$ & OR & CI 95\% \\
\hline \multirow[t]{2}{*}{ Perspective taking } & $\begin{array}{l}\text { Correctly } \\
\text { Classified }\end{array}$ & $55.6 \%$ & 0.07 & 0.027 & 6.16 & 0.13 & 1.06 & \multirow[t]{2}{*}{$1.0-0.12$} \\
\hline & Constant & & -1.30 & 6.49 & 4.03 & 0.45 & 0.27 & \\
\hline \multirow[t]{2}{*}{ Fantasy } & $\begin{array}{l}\text { Correctly } \\
\text { Classified }\end{array}$ & $59.1 \%$ & 0.09 & 0.025 & 12.18 & $<0.001$ & 1.09 & \multirow[t]{2}{*}{$1.04-1.15$} \\
\hline & Constant & & -1.75 & 5.90 & 8.74 & 0.003 & 0.17 & \\
\hline \multirow[t]{2}{*}{ Personal discomfort } & $\begin{array}{l}\text { Correctly } \\
\text { Classified }\end{array}$ & $60.3 \%$ & -0.15 & 0.032 & 22.14 & $<0.001$ & 0.86 & \multirow[t]{2}{*}{$0.81-0.92$} \\
\hline & Constant & & & & & $<0.001$ & 12.49 & \\
\hline
\end{tabular}

Note: B = Regression coefficient; E.T. = Standard error; Wald = Wald's test; $p=$ Probability; OR = Odd ratio; C.I. $=95 \%$ confidence interval.

For perspective taking, the Hosmer and Lemeshow test indicated that there are no differences between the predicted data and those observed in perspective taking $\left(\chi^{2}=6.78, p=0.45\right)$, in fantasy $\left(\chi^{2}=11.84, p=0.16\right)$, and in personal discomfort $\left(\chi^{2}=13.15, p=0.08\right)$.

The findings allow a correct estimate of the perspective taking variable to be made in $55.6 \%$ of the cases $\left(\chi^{2}=6.33 ; p=0.013\right)$, being the adjustment values of 0.02 for $R^{2}$ of Nagelkerke, of 0.01 for $R^{2}$ of Cox and Snell 0.01 and of 616.91 for -2log. of the plausibility, the components of the model reflected by the $O R$ indicated that the probability of presenting a high self-efficacy was 1.06 higher for each point of increase in the perspective variable. In other words, the possibility of presenting high perceived academic self-efficacy increased by $6 \%$. Regarding the fantasy variable, the results indicated a correct estimate in $59.1 \%$ of the cases $\left(\chi^{2}=12.60 ; p=<0.001\right)$, being the adjustment values of 0.04 for $\mathrm{R}^{2}$ of Nagelkerke, of 0.03 for $\mathrm{R}^{2}$ of Cox and Snell and of 620.64 for $-2 \log$. of the plausibility. The components of the model expressed by the $O R$ indicated that the probability of presenting high perceived academic self-efficacy was 1.09 higher for each fantasy increase point, so that the high academic self-efficacy increased by $9 \%$. Finally, a correct estimate of the personal discomfort variable was made in $60.3 \%$ of cases $\left(\chi^{2}=23.66 ; p=<0.001\right)$, being the adjustment values of 0.07 for $R^{2}$ of Nagelkerke, of 0.05 for $R^{2}$ of Cox and Snell, and of 609.58 for -2log. of the plausibility. The components of the model reflected by the $O R$ indicated that the possibility of presenting high perceived academic self-efficacy was 0.86 for each point of increase in personal discomfort. In other words, the probability of presenting high academic self-efficacy decreased by $14 \%$.

\section{Discussion}

There were several objectives of the present study. On the one hand, the current work aimed to analyze whether perceived academic self-efficacy is significantly correlated with all dispositional empathy factors. On the other hand, if there are differences in dispositional empathy with low and high academic self-efficacy perceived in future teachers. Likewise, the study tried to examine the predictive capacity of the dimensions of dispositional empathy on high perceived academic self-efficacy.

Regarding the first objective, from the correlations between perceived academic self-efficacy and dispositional empathy, the results found positive and significant correlations between perspective taking 
and fantasy, which would partially confirm the first hypothesis. Likewise, negative and significant correlations were obtained between personal discomfort and perceived academic self-efficacy, which would confirm the second hypothesis.

Similarly, with respect to the second objective, it should be noted that the study findings show statistically significant differences in the dimensions of dispositional empathy, between high and low perceived academic self-efficacy, except for empathic concern. Under these results, the third hypothesis is partially confirmed, since it was expected to obtain significant differences in all dimensions of dispositional empathy except for fantasy [35].

This study corroborates that future teachers with high perceived academic self-efficacy, contrary to those with low perceived academic self-efficacy, present less personal discomfort, as well as an empathic trait defined by a greater perspective taking and fantasy, with no significant scores in term of empathic concern (see Table 4). Within these differences, and under the observed findings, the fourth hypothesis would also be partially confirmed, since the results of the analyzes show that university students with high perceived academic self-efficacy have higher means of taking perspective and fantasy than students with low perceived academic self-efficacy. However, there was no significance for empathic concern. These results are discussed below.

The reason why the results do not coincide exactly with the proposed hypotheses may be due to the sample of participants in the study by Dionigi et al. [35], because those who directed that empathy were children from the hospital. The empathy of the participants of the present work will be aimed at children and adolescents with a wide diversity, but who are generally not ill. This denotes that the results of this study are more encouraging.

Regarding perspective taking, the sample of high perceived self-efficacy could be due to several reasons - on the one hand, the high motivation of students with high academic self-efficacy compared to students with low academic self-efficacy. The existing literature shows that personal well-being predicts academic performance [47]. Likewise, studies that analyze logistic regressions with similar variables in opposite ways affirm that self-efficacy is a predictor of well-being in age diversity [48,49], which is the reason why it is associated with a positive mental state [34] and, in turn, is a precursor to the development of a positive academic [10,12] and general self-concept [50]. On the other hand, self-efficacy increases self-esteem and reduces anxiety [51]. All these influences can trigger a feeling of happiness that allows the subject to go beyond their own perspective, allowing them to put themselves in the other's place. In the same way, interacting with someone who has high dispositional empathy increases the other person's feelings of happiness [34]. These results also confirm that a greater degree of perspective taking is added to this greater personal well-being.

In the absence of studies that examine the link between perceived academic self-efficacy and fantasy, it should be noted that the influence of future thoughts can condition the behavior in positive or negative, and this will depend on the character of those thoughts. It can be observed that self-efficacy can have a positive motivational influence $[14,51,52]$ and, moreover, that motivation contributes towards this high efficacy for the healing of various diseases, possibly due to its placebo effect [53]. Therefore, with a motivational increase as a result of this academic performance, whether with a higher or lower realistic character, this perceived academic self-efficacy and self-confidence will increase [13,51]. Academic self-efficacy is more predictive of academic performance than other cognitive variables [54], which implies that in the same way that the executive functions [15]; subjective beliefs also have an influence [23].

Regarding the differences in dispositional empathy depending on the high or low self-efficacy that the academic perceived, it should be noted that, based on the previous observed literature [36-38], the fifth hypothesis stated that the low perceived academic self-efficacy could present significantly higher averages in personal discomfort with respect to the high perceived academic self-efficacy.

Based on the findings, it can be determined that the fifth hypothesis is confirmed. This shows that this level of dispositional empathy when activating fear, anxiety and lack of control fosters negative beliefs of self-efficacy due to their presumption of failure [36-38]. It should be remembered that a 
low level of academic self-efficacy can trigger negative consequences not only academic but also personal [4] and that it is predictive of emotional exhaustion [55]. In other words, within one's own dispositional empathy, the fact of thinking about a tense and uncomfortable situation can make the person feel personal discomfort because they feel overwhelmed.

However, it seems that if the mind is focused on the power and ability of the person to carry out any task [8,9], feelings of control and confidence increase [13], resilience [20] and self-acceptance and mastery of the environment [23], and the mind is therefore focused on the positive aspects and the belief in power to manage. In this regard, Bandura [56] states that people facilitate their levels of opportunity when they cultivate not only their interests but also the facilitating skills and beliefs.

On the other hand, in relation to the third objective, which attempted to analyze the predictive capacity of dispositional empathy dimensions on a high level of perceived academic self-efficacy, it should be noted that after the observed findings, the sixth hypothesis is partially confirmed. Recall that the likelihood of high perceived academic self-efficacy was expected to be greater as perspective taking and empathic concern increased. However, empathic concern was not significant while fantasy was significant. Similarly, the seventh hypothesis is confirmed by finding that the probability of presenting a high perceived academic self-efficacy is less as personal discomfort increases. Next, each of these findings is discussed.

It seems that putting yourself in another's place and obtaining different points of view positively influences the beliefs of your own academic effectiveness. In this sense, among the scarce amount of studies that examine these variables, some works that affirm that perspective taking is essential for teamwork [57] can be found, and this in turn tends to have greater self-efficacy and academic achievement results [26]. Likewise, Sánchez-Rosas [58] observed that academic social self-efficacy positively and significantly correlated with enjoyment and hope for the activities carried out in the classroom jointly between university students.

In this regard, the results found denote that future teachers perceive a greater academic competence when carrying out the work from different points of view. In this sense, methodologies such as group work would be approached, which influences not only the content and academic performance but also social relations [59]. However, despite the positive benefits of group work [59,60], this assessment should be studied because it is not without difficulties considering that the teacher must be competent in their organization and management of the space [61]. Therefore, considering the findings of this study on the functioning of future teachers' minds in terms of self-efficacy, instruction on classroom management and organization must be promoted from the Faculties of Education.

On the other hand, it is observed that the probability of presenting a high perceived academic self-efficacy is 1.09 for each increase point in fantasy. Despite encountering controversies regarding the concept of fantasy and how it influences people's minds, which is related to neuroticism [62] and hallucinatory experiences [63], various studies affirm the benefits of fantasy thoughts on the development of imagination and creativity [64], openness to experience [62], behavioral self-regulation [65] and emotional regulation strategies [66]. In fact, there are problem-solving strategies based on mental simulation in which visual imagination is key in the process [67-70]. In addition, there are some studies that use visual images to enhance social relationships [71,72]. Therefore, these findings denote that simulation of future work influences its outcome. It should be noted that, sometimes, people represent the future through thoughts, which serve as guides and motivations [56]. However, those motivations influence current behavior, and although the future should not be the cause of current behavior because there is no real, living existence, cognitive influence makes emotional changes.

Moreover, the results of this study indicate that the probability of presenting high perceived academic self-efficacy with the presence of personal discomfort decreases by $14 \%$, which aligns with other studies. These findings are understandable when considering self-efficacy is related to psychological well-being $[23,34,48,50]$, which is sustained by a state of happiness and satisfaction with life [23]. Bermejo-Toro and Prieto-Ursúa [39], in a study on teacher's discomfort and self-efficacy beliefs, 
obtained that the perception of negative efficacy was linked to a greater number of sick leaves due to burnout syndrome (i.e., the negative psycho-social consequences which trigger chronic stress and distant and hopeless behavior [39]). Here, again we could return to the statements of Bandura [56] and Sánchez-Rosas [57] about maladaptive behavior that can lead to a low level of self-efficacy. Hence, it is encouraged that the Faculties of Education offer courses or subjects where one works with resources and personal regulation strategies and trained is given to increase the students' social development.

Interacting with someone who has dispositional empathy can be rewarding for people. However, it seems that the effort to be empathetic on purpose does not obtain the same results [34]. In fact, it seems that conscious attention for being empathetic can be counterproductive, damaging the resolution of a task [34,73]. For this reason, authors such as Vorauer, Petsnik and Quesnel [34] warn of the importance of not working empathy in the moment of conflict, but rather working empathy and interpersonal intelligence from a solid base that increases socio-emotional learning and that facilitates the change in person over time. In other words, it is recommended to promote social skills development programs with the aim of moving from a motivation and effort to be empathetic to a presence of dispositional empathy in the person.

Finally, corroborating the previous results and considering all the above, it is possible that the fact that empathic concern does not present significance may be due to the compassionate characteristic of the dimension. That is, from a sample such as that of Dionigi et al. [35] (hospital volunteers), it is logical that greater compassion can be presented for the people with whom one empathizes; however, from a sample of future teachers, empathy should be to the benefit of putting oneself in the place of another, but not for acting compassionately or with fear or anxiety. In this sense, the results found from the study encourage a positive benefit from the link between both variables. For if not, the belief in negative self-efficacy weakens the ability to strive for action. Furthermore, it seems that a belief of effectiveness that affects the emotional quality and vulnerability of the person could influence the decrease in perspective taking, which has a greater insensitivity to the opinion or feelings of others. In fact, when a person is depressed, they have low psychological power, which increases sensitivity to the actions of others and can increase reactivity to empathy [34]. Therefore, faced with a difficulty of these characteristics where a person's level of self-efficacy is low, whether they are students or teachers, it could negatively influence relationships with others. For this reason, it is considered necessary to increase scientific knowledge on the subject. In addition, it is considered important to work on the subject from the first years of teaching studies. In other words, future teachers must develop resources and strategies for personal and self-regulation, as well as strategies for developing social skills for their future students.

However, as has been shown in the present study, a high perceived academic self-efficacy presents a lower degree of personal discomfort and a higher level of perspective and fantasy taking. In this sense, and although the results are encouraging, it is recommended not only to work with these intrapersonal and interpersonal strategies, but also to continue working from methodologies that increase motivation for studies [14], confidence [13] and academic self-concept of university students, an aspect that binds to the high perceived academic self-efficacy $[10,12]$.

The current need to instruct effective social development, both physically and virtually, should be considered. It should be noted that, in general, young people who make use of the Internet daily tend to spend most of their time online and social networks [74] and who are prone to share their life in images online and create their own identity [75]. In this sense, it is important to bear in mind that excessive browsing through social networks can limit the oral communication of young people [74]. However, encouragingly, it seems that although self-efficacy is associated with greater use of technology and social networks [22], it is not associated with greater exposure of personal images on social networks [76]. 


\section{Limitations and Future Research}

There are several limitations of this study. One of them is directed towards the characteristics of the sample. Considering that the sample is made up of Spanish university students, the results should not be generalized to the entire Spanish population or to all countries and cultures. Hence, a future line of research should check if there are differences in the results of the study with respect to different countries and cultures, as well as the Spanish adolescent and infant-youth sample.

On the other hand, the cross-sectional nature of the studies prevents establishing causal relationships between the variables studied. Hence, future works should address this lack through the method of structural equations or longitudinal data.

Likewise, the analyzes were carried out through the administration of self-reports, so it may carry with it a bias of acquiescence and social desirability [77]. That is why future studies should assess or increase the study findings from a multi-method evaluation, with semi-structured interviews. Despite observing adequate internal consistency and reliability indices for the two scales administered, it would be convenient to replicate the study with similar scales that assess the same variables in order to determine if the results are similar or vary from one to other measurement scales.

Finally, it should be noted that this study did not consider the differences between sexes. Sex was not used as a control variable since the differences in low academic self-efficacy were not statistically significant $(t(803)=0.106, p=0.92$, the women obtained an $M=30.83$ and $S D=6.16$ and men $M=30.89$ and $S D=6.17$ ). However, future studies should test these differences again by considering that, despite observing slight gender differences, previous studies such as Huang's [78] observed that academic self-efficacy scored higher in men than in women.

\section{Conclusions}

Despite the limitations of the work, this study has several educational implications. According to the literature reviewed, this study is the first to address the link between self-efficacy and the different variables of dispositional empathy. Therefore, it has enriched the research on the perceived academic self-efficacy of future teachers.

Likewise, after focusing on the objectives-analyzing the correlations between perceived academic self-efficacy and dispositional empathy, examining if there are statistically significant differences in the dimensions of dispositional empathy between high and low perceived academic self-efficacy, as well as analyzing the predictive capacity of empathy dispositional on high perceived academic self-efficacy—several practical and theoretical conclusions have been highlighted.

The results confirm that the correlations are positive and significant for perceived academic self-efficacy, perspective taking and fantasy, and negative and significant for personal discomfort. In addition, the findings of the study highlight a greater perspective taking and fantasy in future teachers, with less personal discomfort in a high academic self-efficacy as opposed to those with low perceived academic self-efficacy. Furthermore, the findings show that perspective taking and fantasy are a predictor of perceived academic self-efficacy, and that personal discomfort decreases perceived academic self-efficacy. These findings confirm the second, fifth and seventh hypotheses. However, the other hypotheses are partially confirmed by not observing significance in empathic concern.

The results of the study highlight the indirect interpersonal benefit and influence the reflection on the need to offer necessary instructional programs for future teachers. Therefore, the instruction of future teachers in classroom management, organization, and cooperative work methodologies are encouraged, as well as the instruction of emotional regulation programs and the development of social skills, and mental simulation strategies on positive results and future events.

It is needed to present adequate self-efficacy in the teaching group, not only to show performance and academic success in terms of their training, as previous studies affirm $[4,9,10]$, but also because of its link with perspective taking and fantasy as well as its distance from personal discomfort, which will indirectly favor future students in both early childhood and primary education teaching degrees. 
Author Contributions: For the article conceptualization, M.P.A.-F. and J.D.Á.-T.; methodology, J.M.E.-F.; software, R.P.E.-F.; formal analysis, J.M.E.-F.; investigation, M.P.A.-F. and J.D.Á.-T.; resources, M.P.A.-F.; data curation, J.D.Á.-T.; writing—original draft preparation, M.P.A.-F. and J.D.Á.-T.; writing—review and editing, M.P.A.-F., J.M.E.-F. and R.P.E.-F.; visualization, J.M.E.-F. and R.P.E.-F.; supervision, M.P.A.-F., J.D.Á.-T., J.M.E.-F. and R.P.E.-F.; project administration, M.P.A.-F., J.M.E.-F., R.P.E.-F. and J.D.Á.-T. All authors have read and agreed to the published version of the manuscript.

Funding: This research received no external funding.

Conflicts of Interest: The authors declare no conflict of interest

\section{References}

1. Klassen, R.M.; Ming-Chiu, M. The occupational commitment and intention to quit of practicing and pre-service teachers: Influence of self-efficacy, job stress, and teaching context. Contemp. Educ. Psychol. 2011, 36, 114-129. [CrossRef]

2. Klassen, R.M.; Durksen, T.L. Weekly self-efficacy and work stress during the teaching practicum: A mixed methods study. Learn. Instr. 2014, 33, 158-169. [CrossRef]

3. Karabiyik, B.; Korumaz, M. Relationship between teachers' self-efficacy perceptions and job satisfaction level. Procedia-Soc. Behav. Sci. 2014, 116, 826-830. [CrossRef]

4. Domínguez-Lara, S.A. Valores normativos de una escala de autoeficacia académica en estudiantes universitarios de Lima. Interacciones 2016, 2, 91-98. [CrossRef]

5. Liu, X.; Gao, X.; Ping, S. Post-1990s college students academic sustainability: The role of negative emotions, achievement goals, and self-efficacy on academic performance. Sustainability 2019, 11, 775. [CrossRef]

6. Waxman, H.C.; Gray, J.P.; Padron, Y.N. Review of Research on Educational Resilience: Research Report; Institute of Education Sciences: Washington, DC, USA, 2003.

7. Wolgast, A.; Tandler, N.; Harrison, L.; Umlauft, S. Adult's dispositional and situational perspective-taking: A systematic review. Educ. Psychol. Rev. 2020, 32, 353-389. [CrossRef]

8. Bandura, A. Self-Efficacy: The Exercise of Control; W. H. Freeman: New York, NY, USA, 1997.

9. García-Fernández, J.M.; Inglés, C.J.; Vicent, M.; Gonzálvez, C.; Pérez-Sánchez, A.M.; Lagos-San Martín, N. Validación de la escala de Autoeficacia Percibida Específica de Situaciones Académicas en Chile y su relación con las estrategias de aprendizaje [Validation of the Academic Situations Specific Perceived Self-efficacy Scale in Chile and its relation with learning strategie]. Rev. Iberoam. Diagn. Eval.-Aval. Psicol. 2016, 41, 118-131.

10. García-Fernández, J.M.; Inglés, C.J.; Torregrosa, M.S.; Ruiz-Esteban, C.; Díaz-Herrero, A.; Pérez-Fernández, E.; Martínez-Monteagudo, M.C. Propiedades psicométricas de la Escala de Autoeficacia Percibida Específica de Situaciones académicas en una muestra de estudiantes españoles de Educación Secundaria Obligatoria. Eur. J. Educ. Psychol. 2010, 3, 61-74. [CrossRef]

11. García-Fernández, J.M.; Inglés, C.J.; Vicent, M.; Gonzálvez, C.; Lagos-San Martín, N.; Pérez-Sánchez, A.M. Relación entre autoeficacia y autoatribuciones académicas en estudiantes chilenos [Relationship between self-efficacy and academic self-attributions in Chilean students]. Univ. Psychol. 2016, 15, 15-24. [CrossRef]

12. Bong, M.; Skaalvik, E.M. Academic self-concept and self-efficacy: How different are they really? Educ. Psychol. Rev. 2003, 15, 1-40. [CrossRef]

13. Duffy, R.D.; Douglass, R.P.; Autin, K.L. Career adaptability and academic satisfaction: Examining work volition and self efficacy as mediators. J. Vocat. Behav. 2015, 90, 46-54. [CrossRef]

14. Ross, M.; Perkins, H.; Bodey, K. Academic motivation and information literacy self-efficacy: The importance of a simple desire to know. Libr. Inform. Sci. Res. 2016, 38, 2-9. [CrossRef]

15. Alegre, A.A. Autoeficacia académica, autorregulación del aprendizaje y rendimiento académico en estudiantes universitarios iniciales [Academic self-efficacy, self-regulated learning and academic performance in first-year university students]. Prop. Represent. 2014, 2, 79-120.

16. Zimmerman, B.J.; Kitsantas, A.; Campillo, M. Evaluación de la autoeficacia regulatoria: Una perspectiva social cognitiva. Evaluar 2005, 5, 1-21.

17. Seetee, N.; Chi, C.; Dhir, A.; Chen, S. Validation of the science, mathematics, and English task value scales based longitudinal data. Int. J. Sci. Math. Educ. 2020, 1-18. [CrossRef]

18. Alhadabi, A.; Karpinski, A.C. Grit, self-efficacy, achievement orientation goals, and academic performance in university students. Int. J. Adolesc. Youth 2020, 25, 519-535. [CrossRef] 
19. Tuckman, B.; Monetti, D. Psicología Educativa; Cengage Learning: CDMX, Mexico, 2011.

20. Cassidy, S. Resilience building in students: The role of academic self-efficacy. Front. Psychol. 2015, 6, 1-14. [CrossRef]

21. Oros, L.B. Valores normativos de la Escala Multidimensional de Autoeficacia Infantil para población argentina [Normative Data of Multidimensional Scale of Self-Efficacy for children]. Rev. Iberoam. Diagn. Eval.-Aval. Psicol. 2017, 44, 172-181. [CrossRef]

22. Dhir, A.; Khalil, A.; Puneet, K.; Risto, R. Rationale for "Liking” on Social Networking Sites. Soc. Sci. Comput. Rev. 2019, 37, 529-550. [CrossRef]

23. González-Cabanach, R.; Valle-Arias, A.; Freire-Rodríguez, C.; Ferradás-Canedo, M. Relaciones entre la autoeficacia percibida y el bienestar psicológico en estudiantes universitarios [The relations between perceived self-efficacy and psychological well-being in university students]. Rev. Mex. Psicol. 2012, 29, 40-48.

24. Hernández-Fernaud, E.; Ramos-Sapena, Y.; Negrín, F.; Ruiz-de la Rosa, C.I.; Hernández, B. Empleabilidad percibida y autoeficacia para la búsqueda de empleo en universitarios [Perception of employability and self-efficacy for job seeking in university students]. Rev. Psicol. Trab. Organ. 2011, 27, 131-142.

25. Allan, B.A.; Sterling., H.M.; Duffy, R.D. Longitudinal relations among economic deprivation, work volition, and academic satisfaction: A psychology of working perspective. Int. J. Educ. Vocat. Guid. 2020, 20, 311-329. [CrossRef]

26. Stump, G.S.; Hilpert, J.C.; Husman, J.; Chung, W.; Kim, W. Collaborative learning in engineering students: Gender and achievement. J. Eng. Educ. 2013, 100, 475-497. [CrossRef]

27. Gutiérrez-Del Moral, M.J. El trabajo cooperativo, su diseño y su evaluación. Dificultades y propuestas. In Proceedings of the II Congreso Internacional Univest’09, Universidad de Girona, Girona, Spain, 12-13 November 2009.

28. Moya-Albiol, L.; Herrero, N.; Bernal, M.C. Bases neuronales de la empatía. Rev. Neurol. 2010, 50, 89-100. [CrossRef] [PubMed]

29. Želaźniewicz, A.; Nowak, J.; Groyecka, A.; Sorokowski, P.; Dobrowolska, M.; Pawlowski, B. Empathy and oxidative stress in healthy adults. Sustainability 2020, 12, 4959. [CrossRef]

30. Auné, S.E.; Abad, F.J.P.; Attorresi, H.F. Antagonismos entre concepciones de empatía y su relación con la conducta prosocial. Rev. Psicol. 2015, 17, 137-149. [CrossRef]

31. Mattan, B.D.; Rotshtein, P.; Quinn, K.A. Empathy and visual perspective-taking perfomance. Cogn. Neurosci. 2016, 7, 170-181. [CrossRef]

32. Pérez-Albéniz, A.; De Paúl, J.; Etxeberría, J.; Montes, M.P.; Torres, E. Adaptación de Interpersonal Reactivity Index (IRI) al español. Psicothema 2003, 15, 267-272.

33. Rameson, L.T.; Morelli, S.A.; Lieberman, M.D. The neural correlates of empathy: Experience, automaticity and prosocial behavior. J. Cogn. Neurosci 2012, 24, 235-245. [CrossRef]

34. Vorauer, J.D.; Petsnik, C.; Quesnel, M.S. Who brings you up when you're feeling down? Distinct implications of dispositional empathy versus situationally-prompted empathic mindsets for target's affective experience in face-to-face interpersonal interaction. J. Exp. Soc. Psychol. 2020, 89, 1-12. [CrossRef]

35. Dionigi, A.; Casu, G.; Gremigni, P. Empathy adds incrementally to the association of self-efficacy and optimism with psychological health in healthcare volunteers. Prepints 2020. [CrossRef]

36. Putwain, D.W.; Symes, W. The impact of fear appeals on subjective-task value and academic self-efficacy: The role of appraisal. Learn. Individ. Differ. 2016, 51, 307-313. [CrossRef]

37. Razavi, S.A.; Shahrabi, A.; Siamian, H. The relationship between research anxiety and self-efficacy. Mater. Sociomed. 2017, 19, 217-250. [CrossRef] [PubMed]

38. Roick, J.; Ringeisen, T. Self-Efficacy, test anxiety and academic success: A longitudinal validation. Int. J. Educ. Res. 2017, 83, 84-93. [CrossRef]

39. Bermejo-Toro, L.; Prieto-Ursúa, M. Malestar docente y creencias de autoeficacia del profesor. Rev. Esp. Pedagog. 2005, 232, 493-510.

40. Bianchi, R.; Schonfeld, I.S.; Vandel, P.; Laurent, E. On the depressive nature of the "burnout syndrome": A clarification. Eur. Psychiatr. 2017, 41, 109-110. [CrossRef]

41. Goroshit, M.; Hen, M. Teacher's empathy: Can it be predicted by self-efficacy? Teach. Teach. Theor. Pract. 2016, 22, 805-818. [CrossRef]

42. Jennings, P.A.; Greenberg, M.T. The prosocial classroom: Teacher social and emotional competence in relation to student and classroom outcomes. Rev. Educ. Res. 2009, 79, 491-525. [CrossRef] 
43. Palenzuela, D. Construcción y validación de una escala de autoeficacia percibida específica de situaciones académicas. Anal. Modif. Cond. 1983, 9, 185-219. [CrossRef]

44. Domínguez, S.; Villegas, G.; Yauri, C.; Mattos, E.; Ramírez, F. Propiedades psicométricas de una escala de autoeficacia para situaciones académicas en estudiantes universitarios peruanos. Rev. Psicol. UCSP 2012, 2, 27-39.

45. Cohen, J. Statistical Power Analysis for the Behavioral Sciences; Erlbaum: Hillsdale, NJ, USA, 1988.

46. De Maris, A. Logistic regression. In Research Methods in Psychology; En Schinka, J.A., Velicer, W.F., Eds.; John Willey \& Sons: Hoboken, NJ, USA, 2003; pp. 509-532.

47. Ferragut, M.; Fierro, A. Inteligencia emocional, bienestar personal y rendimiento académico en preadolescentes [Emotional intelligence, well-being and academic achievement in preadolescents]. Rev. Latinoam. Psicol. 2012, 44, 95-104.

48. Fernández-Ballesteros, R. Una Psicología de la Vejez. Una Psicogerontología Aplicada; Pirámide: Madrid, Spain, 2008.

49. Pavón, M.; Arias, C.J. Autoeficacia percibida y creatividad en tres grupos etarios [Perceived self-efficacy and creativity in three age groups]. An. Proy. Inform. Becarios Investig. 2014, 11, 1067-1072.

50. Espada, J.P.; Gonzálvez, M.T.; Orgilés, M.; Carballo, J.M.; Piqueras, J.A. Validación de la Escala de Autoeficacia General con adolescentes españoles. Electron. J. Res. Educ. Psychol. 2012, 10, 355-370. [CrossRef]

51. Mao, Y.; Yang, R.; Bonaiuto, M.; Jianhong, M.; Harmat, L. Can flow alleviate anxiety? The roles of academic self-efficacy and self-esteem in building psychological sustainability and resilience. Sustainability 2020, 12, 2987. [CrossRef]

52. Osei-Boahene, K.; Fang, J.; Sampong, F. Social media usage and tertiary students' academic performance: Examining the influences of academic self-efficacy and innovation characteristics. Sustainability 2019, 11, 2431. [CrossRef]

53. Villamarín, F. Autoeficacia: Investigaciones en psicología de la salud. Anu. Psicol. 1994, 61, 9-18.

54. Olmedo-Moreno, E.M.; Expósito-López, J.; Olmos-Gómez, M.C.; Sánchez-Martín, M.; Chacón-Cuberos, R. Academic self-efficacy in unaccompanied foreign minors: Structural equation modelling according to schooling. Sustainability 2020, 12, 4363. [CrossRef]

55. Domínguez-Lara, S.A. Escala de Cansancio Emocional: Estructura factorial y validez de los ítems en estudiantes de una universidad privada [Emotional Exhaustion Scale: Factorial structure and the validity of the ítems in students of a private university]. Av. Psicol. 2014, 22, 89-97. [CrossRef]

56. Bandura, A. Adolescent development from an agentic perspective. In Self-Efficacy Beliefs of Adolescents; En Pajares, F., Urdan, T., Eds.; In-formation Age Publishing: Greenwich, CT, USA, 2006; pp. 1-43.

57. Gruber, H.E. Creativity and conflict resolution: The role of point of view. In The Handbook of Conflict Resolution: Theory and Practice; En Deutsch, M., Coleman, P.T., Eds.; Jossey-Bass: San Francisco, CA, USA, 2000; pp. 345-354.

58. Sánchez-Rosas, J. Búsqueda de ayuda académica, autoeficacia social académica y emociones de logro en clase en estudiantes universitarios. Rev. Argent. Cienc. Comport. 2013, 5, 35-41.

59. Pujolàs-Maset, P. 9. Pujolàs-Maset, P. 9 ideas clave. In El Aprendizaje Cooperativo; Graó: Barcelona, Spain, 2009.

60. Raviv, A.; Cohen, S.; Aflalo, E. How should students learn in the school science laboratory? The benefits of cooperative learning. Res. Sci. Educ. 2019, 49, 331-345. [CrossRef]

61. González-Fernández, N.G.; García-Ruiz, M.R. El aprendizaje cooperative como estrategia de enseñanza-aprendizaje en psicopedagogía (UC): Repercusiones y valoraciones de los estudios. Rev. Iberoam. Educ. 2007, 42, 1-13.

62. Sánchez-Bernardos, M.L.; Hernández-Lloreda, M.J.; Avia, M.D.; Bragado-Álvarez, C. Fantasy proneness and personality profiles. Imagin. Cogn. Pers. 2015, 34, 327-339. [CrossRef]

63. Parra, A. Testing the model of dissociation for hallucinatory experiences in healthy individuals: Relation to schizotypical personality and fantasy proneness. Rev. Latinoam. Psicol. 2009, 41, 571-586.

64. Kaufman, J.C.; Stemberg, R.J. The Cambridge Handbook of Creativity; Cambridge University Press: New York, NY, USA, 2010.

65. Lack, S.A.; Kumar, V.K.; Arévalo, S. Fantasy proneness creative capacity and styles of creativity. Percept. Mot. Skills 2003, 96, 19-24. [CrossRef]

66. Bacon, A.M.; Charlesford, J.J. Investigating the association between fantasy proneness and emotional distress: The mediating role of cognitive coping strategies. Pers. Individ. Differ. 2018, 135, 157-165. [CrossRef] 
67. Gallopel-Morvan, K.; Gabriel, P.; Gall-Ely, M.L.; Rieunier, S.; Urien, B. The use of visual warnings in social marketing: The case of tobacco. J. Bus. Res. 2009, 64, 7-11. [CrossRef]

68. Hilt, L.M.; Pollak, S.D. Getting out of rumination: Comparison of three brief interventions in a sample of youth. J. Abnorm. Child. Psychol. 2012, 40, 1157-1165. [CrossRef]

69. Hvnegaard, M.; Watkins, E.R.; Poulsen, S.; Rosenberg, N.K.; Gondan, M.; Grafton, B.; Austin, S.F.; Howard, H.; Moeller, S.B. Rumination-Focused cognitive behaviour therapy vs. cognitive behaviour therapy for depression: Study protocol for a randomized controlled superiority trial. Trials 2015, 16, 1-6. [CrossRef]

70. Libby, L.K.; Shaeffer, E.M.; Eibach, R.P.; Slemmer, J.A. Picture yourself at the polls: Visual perspective in mental imagery affects self-perception and behavior. Psychol. Sci. 2007, 18, 199-203. [CrossRef]

71. Dhir, A.; Pallesen, S.; Torsheim, R.; Andreassen, C.S. Do age and gender differences exist in selfie-related behaviours? Comput. Hum. Behav. 2016, 63, 549-555. [CrossRef]

72. Dhir, A.; Torsheim, T. Age and gender differences in photo taggins gratification. Comput. Hum. Behav. 2016, 63, 630-638. [CrossRef]

73. Beilock, S.L.; Carr, T.H.; MacMahon, C.; Starkes, J.L. When paying attention becomes counterproductive: Impact of divided versus skill-focused attention on novice and experienced performance of sensorimotor skills. J. Exp. Psychol. Appl. 2002, 8, 6-16. [CrossRef] [PubMed]

74. Dhir, A.; Chen, S.; Nieminen, M. Predicting adolescent Internet addiction: The roles of demographic technology accessibility, unwillingness to communicate and sought Internet gratifications. Comput. Hum. Behav. 2015, 51, 24-33. [CrossRef]

75. Dhir, A.; Kaur, P.; Lonka, K.; Nieminen, M. Why do adolescents untag photos on Facebook? Comput. Hum. Behav. 2016, 55, 1106-1115. [CrossRef]

76. Dhir, A.; Kaur, P.; Rajala, R. Why do young people tag photos on social networking sites? Explaining user intentions. Int. J. Inform. Manag. 2018, 38, 117-127. [CrossRef]

77. Schames-Kreitchmann, R.; Abad, F.J.; Ponsoda, V.; Nieto, M.D.; Morillo, D. Controlling for response biases in self-report scales: Forced-Choice vs. psychometric modeling of Likert items. Front. Psychol. 2019, 10, 1-12.

78. Huang, C. Gender differences in academic self-efficacy: A meta-analysis. Eur. J. Psychol. Educ. 2013, $28,1-35$. [CrossRef]

(C) 2020 by the authors. Licensee MDPI, Basel, Switzerland. This article is an open access article distributed under the terms and conditions of the Creative Commons Attribution (CC BY) license (http://creativecommons.org/licenses/by/4.0/). 